\title{
In silico characterization of a putative ORF-MAP1138c of Mycobacterium avium subspecies paratuberculosis (MAP) with its implications in virulence
}

\author{
Syed A Hassan ${ }^{1 *}$, Seyed E Hasnain², Sami M Halawani ${ }^{3}$ \\ From 2nd International Genomic Medical Conference (IGMC 2013) \\ Jeddah, Kingdom of Saudi Arabia. 24-27 November 2013
}

\section{Background}

Johne's disease is a chronic mycobacterial infection of the small intestine affecting ruminants worldwide. It is estimated that over $50 \%$ of the European Union (EU) dairy holdings is infected [1]. The causal agent is Mycobacterium avium subspecies paratuberculosis (MAP), a slow-growing, acid-fast bacterium. It is a part of the Mycobacterium avium complex (MAC), which also comprises of opportunistic pathogens of humans, as well as innocuous, environmental bacteria [2]. MAP generally interacts with macrophages via different types of receptors, including Toll-like receptors (TLRs) [3,4]. It has been demonstrated of late that H37Rv1411c (LprG) enhances the recognition of triacylated Mycobacterium tuberculosis glycolipids by TLR2 and thereby restraining the expression of MHC-II molecules and processing of antigen and presentation of MHC restricted antigens by macrophages in a TLR2dependent manner $[5,6]$. However, little is known about how M. paratuberculosis evades and resists this active
$\mathrm{CD}^{+}{ }^{+} \mathrm{T}$-cell response and survives and infects other macrophages, a hallmark of mycobacterial infections. In this context, the identification of antigenic proteins is useful in understanding the immune evasion mechanism of MAP within host macrophages.

\section{Materials and methods}

In this study, a comparative proteomic analysis of an orthologous putative gene MAP1138c or LprG and H37Rv1411c (LprG) was done using online bioinformatics tools namely ProtPram and SignalP 4.1, Phosphor 2.1, ProtScan and Hydropathy plot. The theoretical 3D structure of MAP1138c was generated using SWISS MODEL server using H37Rv1411c (LprG) as template. The secondary and super secondary structures of MAP1138c protein were identified and analyzed using PROMOTIF. The theoretical 3D structure generated was further assessed for its reliability using QMEAN, ANOLEA and GROMOS structure assessment tools of SWISS MODEL server.

Table 1 A comparative study of the physiochemical parameters of MAP1138c and H37Rv1411c (LprG) (*GRAVY (-ve) = hydrophilic nature and (+ve) = hydrophobic nature

\begin{tabular}{llllll}
\hline Protein & $\begin{array}{l}\text { Molecular weight } \\
(\mathrm{kD})\end{array}$ & $\begin{array}{l}\text { Amino acid } \\
\text { composition }\end{array}$ & $\begin{array}{l}\text { Instability Index }(>40= \\
\text { unstable) }\end{array}$ & $\begin{array}{l}\text { Aliphatic } \\
\text { Index }\end{array}$ & $\begin{array}{l}\text { Grand Average of Hydropathicity } \\
(\text { GRAVY)* }\end{array}$ \\
\hline MAP1138c & 24.72 & 238 & 28.31 (Stable) & 89.33 & -0.105 \\
$\begin{array}{l}\text { H37Rv1411C } \\
\text { (LPrG) }\end{array}$ & 24.54 & 236 & 16.11 (Stable) & 86.86 & -0.127 \\
\hline
\end{tabular}

\footnotetext{
* Correspondence: asif_srmcbt@yahoo.com

${ }^{1}$ Faculty of Computing and Information Technology Rabigh, King Abdulaziz

University, PO Box 344, Rabigh 21911, Kingdom of Saudi Arabia

Full list of author information is available at the end of the article
}

(c) 2014 Hassan et al; licensee BioMed Central Ltd. This is an Open Access article distributed under the terms of the Creative Commons Attribution License (http://creativecommons.org/licenses/by/2.0), which permits unrestricted use, distribution, and reproduction in any medium, provided the original work is properly cited. 


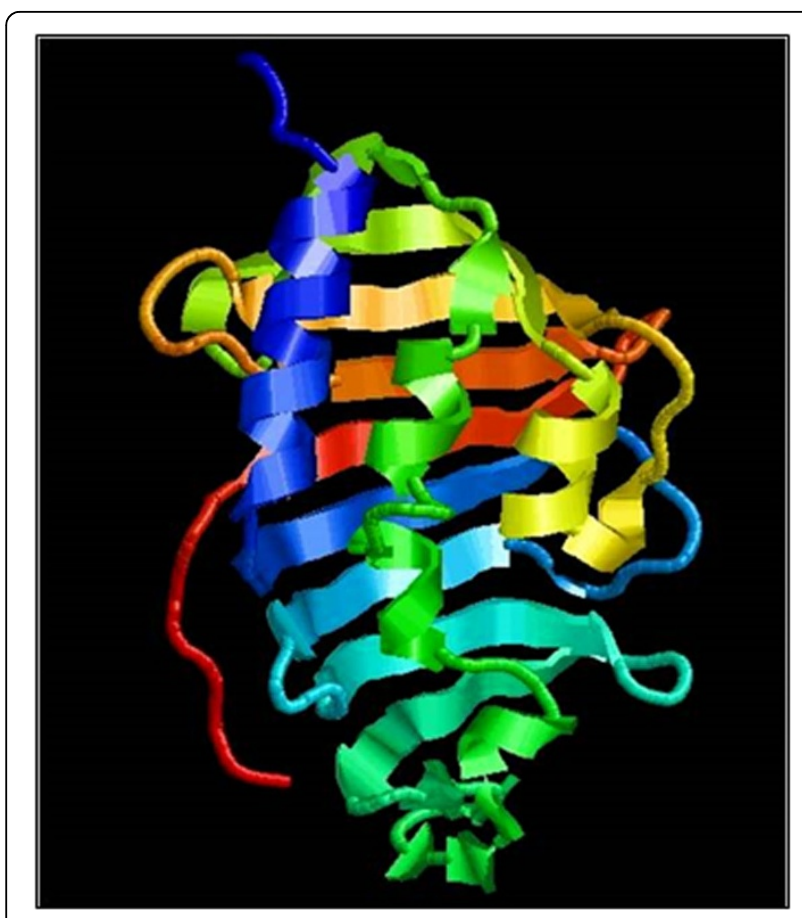

Figure $13 \mathrm{D}$ model of MAP1138c protein generated by SWISSMODEL server.

\section{Results}

Gapped BLAST of MAP1138c identified a homolog having sequence identity match of $70 \%$ and positive match of $83 \%$, respectively with crystal structure of H37Rv1411c (LprG). Proteomics analysis reveals that MAP1138c is a prolipoprotein and is translocated to the cell membrane using Tat pathway and probably the mature protein is secreted out after cleavage by SPase I peptidases. The ProtPram analysis shows similarity in physiochemical parameters namely Grand average of hydropathicity, aliphatic index and instability index for both H37Rv1411c (LprG) and MAP1138c proteins (Table 1).

The comparative hydropathy plot revealed that both MAP1138c and H37Rv-LprG proteins are highly antigenic and hydrophilic by nature. ProtScan domain analysis show the presence of DUF1396 domain specifies that MAP1138c belongs to LppX/LprAFG lipoprotein family of Mycobacterium species and possibly play an important role in the evasion of immune response within host macrophages. The 3D model of MAP1138c, generated by SWISS-MODEL server (Figure 1), shares secondary structure with H37Rv1411c (LprG), as brought forth by PROMOTIF analysis.

The hydrophobic residues lining the central cavity and portal of the protein model supports our hypothesis that like H37Rv1411c-LprG, MAP1138c can bind lipids or

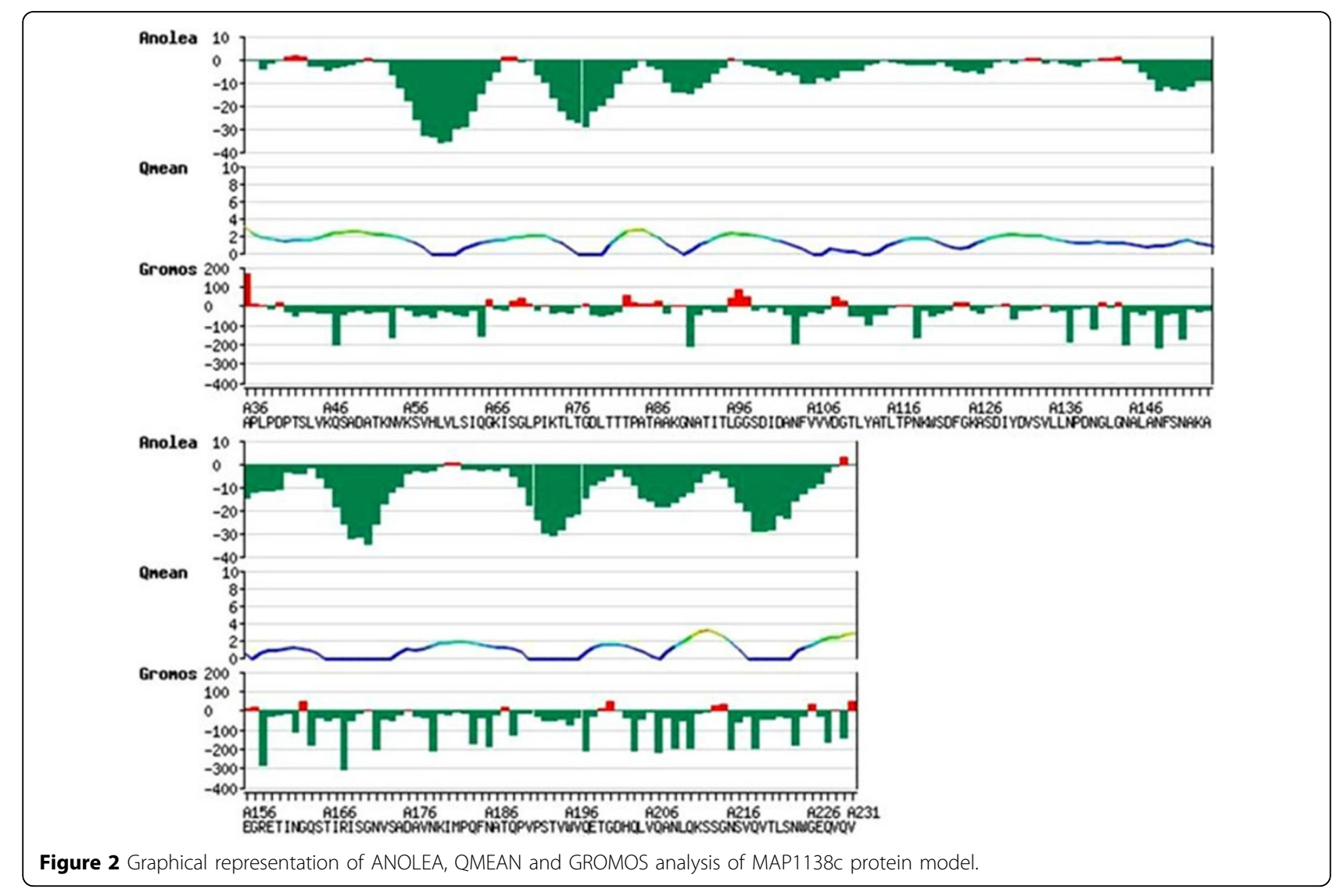


lipopolysaccharides (TLR2 agonists) in the cavity and initiates a TLR2 mediated immune evasion. The analysis of QMEAN , ANOLEA and GROMOS structure assessment tools reveal that the global and local properties of MAP1138c protein model generated by automated SWISS-MODEL server using H37Rv1411c (LprG) as template is reliable and can be used for further analysis (Figure 2).

\section{Conclusions}

Through our comprehensive in silico analysis of MAP1138c, we identified several key aspects fundamentally important to propose a function for this putative protein. These studies reflect upon the possible role of MAP1138c in inhibiting MHC-II Ag processing leading to reduced recognition of infected macrophages by $\mathrm{CD} 4^{+}$ $\mathrm{T}$ cells. This may be an important mechanism for immune evasion during persistent $M$. paratuberculosis infection in ruminants and humans.

\section{Authors' details}

${ }^{1}$ Faculty of Computing and Information Technology Rabigh, King Abdulaziz University, PO Box 344, Rabigh 21911, Kingdom of Saudi Arabia. ${ }^{2}$ Kusuma School of Biological Sciences, Indian Institute of Technology, Hauz Khas, New Delhi 110016, India. ${ }^{3}$ Faculty of Computing and Information Technology Jeddah, P.O. Box 80200, Zip Code 21589, King Abdulaziz University, Kingdom of Saudi Arabia.

\section{Published: 2 April 2014}

\section{References}

1. Nielsen SS, Toft N: A review of prevalences of paratuberculosis in farmed animals in Europe. Prev Vet Med 2009, 88:1-14.

2. Turenne CY, Wallace R Jr, Behr MA: Mycobacterium avium in the postgenomic era. Clin Microbiol Rev 2007, 20:205-229.

3. Ferwerda G, Kullberg BJ, de Jong DJ, Girardin SE, Langenberg DM, van Crevel R, Ottenhoff TH, Van der Meer JW, Netea MG: Mycobacterium paratuberculosis is recognized by Toll-like receptors and NOD2. I Leukoc. Biol 2007, 82:1011-1018.

4. Koets A, Santema W, Mertens H, Oostenrijk D, Keestra M, Overdijk M, Labouriau R, Franken P, Frijters A, Nielen M, Rutten V: Susceptibility to paratuberculosis infection in cattle is associated with single nucleotide polymorphisms in Toll-like receptor 2 which modulate immune responses against Mycobacterium avium subspecies paratuberculosis. Prev Vet Med 2010, 93:305-315.

5. Gehring AJ, Dobos KM, Belisle JT, Harding CV, Boom WH: Mycobacterium tuberculosis LprG (Rv1411c): A Novel TLR-2 Ligand That Inhibits Human Macrophage Class II MHC Antigen Processing. J Immunol 2004, 173:2660-2668.

6. Drage MG, Tsai H-C, Pecora ND, Cheng T-Y, Arida AR, Shukla S, Rojas RE, Seshadri C, Moody DB, Boom WH, Sacchettini JC, Harding CV: Mycobacterium tuberculosis lipoprotein LprG (Rv1411c) binds triacylated glycolipid agonists of Toll-like receptor 2. Nat Struct Mol Biol 2010, 17(9):1088-1095.

doi:10.1186/1471-2164-15-S2-P14

Cite this article as: Hassan et al: In silico characterization of a putative ORF-MAP1138c of Mycobacterium avium subspecies paratuberculosis (MAP) with its implications in virulence. BMC Genomics 2014 15(Suppl 2): P14.

\section{Submit your next manuscript to BioMed Central and take full advantage of:}

- Convenient online submission

- Thorough peer review

- No space constraints or color figure charges

- Immediate publication on acceptance

- Inclusion in PubMed, CAS, Scopus and Google Scholar

- Research which is freely available for redistribution

Submit your manuscript at www.biomedcentral.com/submit
C Biomed Central 